\title{
FAUNAL ANALYSIS AND POPULATION DENSITY OF FRUIT FLIES (DIPTERA: TEPHRITIDAE) IN AN ORCHARD LOCATED IN THE CENTRAL WESTERN REGION OF MINAS GERAIS, BRAZIL
}

\author{
ANÁLISE FAUNÍSTICA E DENSIDADE POPULACIONAL DE MOSCAS-DAS- \\ FRUTAS (DIPTERA: TEPHRITIDAE) EM POMARES LOCALIZADOS NA REGIÃO \\ CENTRO-OESTE DE MINAS GERAIS, BRASIL
}

\author{
Pedro Augusto Silva DUARTE ${ }^{1}$; Flávio Roberto Mello GARCIA ${ }^{2}$; Vanessa ANDALÓ ${ }^{3}$ \\ 1. Instituto Federal de Educação, Ciência e Tecnologia de Minas Gerais - IFMG, Bambuí, MG, Brasil; 2. Programa de Pós-graduação \\ em Entomologia, Instituto de Biologia, Universidade Federal de Pelotas - UFPEL, Pelotas, RS, Brasil; 3. Instituto de Ciências Agrárias, \\ Universidade Federal de Uberlândia - UFU, Monte Carmelo, MG, Brasil. vanessaandalo@ufu.br.
}

\begin{abstract}
Fruit flies are considered important pests of world fruit production, causing significant losses in yield and limiting the free movement of fruit due to the restrictions imposed by importing countries. Thus, the objective of the study was to investigate the infestation rates and faunal analysis to characterize the fruit fly assemblage in an orchard located in Bambuí, MG, Brazil. To this end, samples were taken weekly with fly traps hung in the trees, at a height of about $1.60 \mathrm{~m}$ height. Faunal analysis and study of infestation rates were conducted. The captured species were Ceratitis capitata, Anastrepha grandis, A. fraterculus, A. pseudoparallela, A. obliqua, A. dissimilis, A. zenildae, A. sororcula, A. similis, A. aczeli and A. bistrigata. The species varied throughout the studied period, but only $C$. capitata reached an economic threshold requiring better management of these insects in areas with citrus, acerola and fig. The predominant species was $C$. capitata.
\end{abstract}

KEYWORDS: Anastrepha. Ceratitis. Fruticulture. Tephritids. Survey.

\section{INTRODUCTION}

Brazil occupies third place in the ranking of the largest producers of fruits, after China and India, with a cultivated area of 2.18 million hectares. Production exceeded 41 million tons in 2009 , and the fruits that contribute most to the total volume of Brazilian production are orange, banana, pineapple, watermelon and papaya, which together account for approximately 30 million tons (ANUÁRIO BRASILEIRO DE FRUTICULTURA, 2014; IBRAF, 2015). Despite the large volume of production, the country allocates a small amount of fresh fruits to the foreign market, 711,869 tons of fruit, about $3 \%$ of production (ANUÁRIO BRASILEIRO DE FRUTICULTURA, 2014)

Fruit flies are dipterous, belonging to the Tephritidae family, and their larvae destroy the fruit pulp where the eggs were deposited, making them unsuitable for consumption. The hole made by oviposition serves as a gateway for the entry of pathogens, which then cause decay and fall of the fruit. Fruits exposed to the sun were the ones most attacked. These insects can occur throughout the year, due to the great diversity of fruit that they attack (ZUCCHI, 2000b; GARCIA, 2009).

In Brazil, the fruit flies species of greatest economic importance belong to the genera Anastrepha, Bactrocera and Ceratitis. However, from the agricultural point of view, Ceratitis capitata (Wiedemann, 1824) (Diptera: Tephritidae) and seven of the 115 species of the genus Anastrepha that occur in the country are economically relevant, infecting hundreds of fruit species (ZUCCHI, 2000b, ZUCCHI, 2008).

The presence of tephritid larvae in fruit causes significant losses in yield, puts off consumers and limits the free movement of fresh fruits due to restrictions imposed by importing countries. Losses in fruit production due to the presence of fruit flies in Brazil can amount to 50\% in a crop if pest control measures are not used (ANUÁRIO BRASILEIRO DE FRUTICULTURA, 2013).

In this context, the aim of this study was to characterize the assemblage of fruit flies in a diverse orchard consisting of citrus, acerola, fig and guava, installed in the region of Bambuí (Minas Gerais state, Brazil) and verify the infestation rates and faunal analysis, relating it to the level of control of the populations occurring in this region.

\section{MATERIAL AND METHODS}

\section{Characteristics of sampling areas}

The collections of the fruit flies took place in diverse orchards located in the Instituto Federal de Minas Gerais (IFMG), Campus Bambuí, Fazenda Varginha in the municipality of Bambuí, MG; geographic coordinates $\left(20^{\circ} 02^{\prime} 22.73^{\prime \prime S}\right.$ and 
$46^{\circ} 00^{\prime} 29.39^{\prime \prime} \mathrm{W}$ ) and elevation of $697 \mathrm{~m}$. The climate is high-altitude tropical, classified by Köppen as Cwa, with a dry winter and rainy summer, average annual minimum temperature and maximum $22.0^{\circ} \mathrm{C}$ and $28.4^{\circ} \mathrm{C}$, respectively, and average annual rainfall of $1,272 \mathrm{~mm}$. The collection of material for study was performed every seven days, in a period of ten months, which began in November 2011 and finished in August 2012.

The IFMG orchard has an area of 2.5 hectares and consists of the following fruit (followed by the percentage of each area): citrus (Citrus spp.) (38.3\%), banana (Musa sp.) (7.6\%), passion fruit (Passiflora spp.) (21.4\%), acerola (Malpighia glabra L.) (6.2\%), guava (Psidium guajava L.) (14.2\%) and fig (Ficus carica L.) $(12.3 \%)$. The soil of the orchard is Eutrophic Red Latosol and the orchard has been established for about 10 years.

The orchard area is divided according to the fruit species. Planted citrus varieties are Pera Rio, Hamlin, Baianinha, Tangerine Poncan, Tahiti Acid Lime, Galego Acid Lime. The planting distance of citrus area is $6 \times 4 \mathrm{~m}$, with about 250 plants. The rootstock is Rangpur Lime. All citrus varieties were considered in the results. The bananas are of the cultivar Marmelo, installed at a distance of $3 \times 2 \mathrm{~m}$, with about 100 plants. The passion fruit was planted at a distance of $4 \times 2.5 \mathrm{~m}$, containing about 200 plants. Acerola is represented by the cultivar Manoa Sweet spaced 5 x $4 \mathrm{~m}$ and contains about 100 plants. Guava cv. Paluma was planted at a distance of $6 \times 5 \mathrm{~m}$ with about 90 plants. Fig cv. Roxo de Valinhos was installed at a distance of $3 \times 2 \mathrm{~m}$ and contains about 50 plants.

\section{Collections}

Within the orchard area modified McPhail traps (made of plastic bottles) were placed in a variable number depending on the size of each fruit-growing area. To cover the entire area and considering their sizes, 20 traps were placed in the citrus area, 10 traps in the acerola area, 10 traps in the guava area and 10 traps in the fig area, The specimens were obtained from collections made through the use of fly traps, made out of a $1.5 \mathrm{~L}$ plastic bottle. Inside the bottle, sugar cane molasses $20 \%$ was added, at approximately $300 \mathrm{~mL} /$ trap. The traps were placed in the trees, at a height of approximately $1.60 \mathrm{~m}$ above the ground, remainingin the field for seven days, and the molasses were periodically replaced. They were placed in the field during all period of survey, independent of the presence of fruit. The insects captured were taken to the laboratory for screening, counting and sexing individuals; they were then placed in vials containing $70 \%$ alcohol for identification. Each survey trap was washed, replenished with bait and again arranged in the field. The surveys were conducted from November 2011 to August 2012, a period in which variation in climatic conditions may occur and also that staggers the presence of fruit in the area, allowing the collection of different species of fruit flies. The specimens obtained from the samples were sent to the specialist Dr. Flávio Roberto Mello Garcia, Federal University of Pelotas, to identify the species.

\section{Faunal index}

Analyses of faunal species of the collected fruit-flies were performed on the basis of indices of frequency, constancy, dominance, richness and diversity. The constancy, frequency and dominance were calculated using the equations proposed by Silveira Neto et al. (1976). Next, species were separated into categories according to Bodenheimer classification (1955) in: constant species (W) present in more than $50 \%$ of the collections; incidental species (Y) - present in $25-50 \%$ of collections; accidental species (Z) - present in less than $25 \%$ of the collections.

The richness (S) was obtained by the total number of species observed in the community, according to Silveira Neto et. al (1976). The diversity index was measured by the diversity index $(\alpha)$, based on the Margalef index (MARGALEF, 1972), which is the ratio between the number of species (S) and the number of individuals in a community $(\mathrm{N})$.

\section{Infestation rates}

The MAD index (fruit fly/trap/day) was used (ARAÚJO et al., 2005; CARVALHO, 2005; SANTOS et al., 2008) to estimate the level of monthly infestation of tephritids in the studied orchards. The index was calculated by the equation: $\mathrm{MAD}=\mathrm{M} / \mathrm{A} \times \mathrm{D}$, where: $\mathrm{M}=$ numberof captured fruit flies; $A=$ number of traps; $D=$ number of days of exposure of traps.

According to Carvalho's (2005) methodology, the values of the MAD index (fruit fly/trap/day) are: Area free - MAD $=0$ (for the target species); Low prevalence in production areas - MAD <0.1, so the orchard can be registered for export; High prevalence - MAD> 0.4; and if MAD $\geq 0.5$, chemical control measures should be initiated for all crops by spraying with toxic baits, using sugarcane molasses or hydrolyzed protein. 
As Anastrepha males are not identified, because they do not present morphological characteristics for their specific recognition (ZUCCHI, 2000a), the calculations included only the number of females of this genus. Therefore, for comparison purposes, only the number of $C$. capitata females was also considered.

\section{RESULTS AND DISCUSSION}

\section{Faunal analysis}

In a period of 10 months of study a total of 3,404 female fruit flies were captured through the use of fly traps. Among these individuals 3,210 are C. capitata and 194 Anastrepha spp. The specimens found belong to the following species: A. grandis (Macquart, 1846), A. fraterculus (Wiedemann, 1830), A. pseudoparallela (Loew, 1873), A. obliqua (Macquart, 1835), A. dissimilis Stone, 1942, A. zenildae Zucchi 1979, A. sororcula Zucchi, 1979, A. similis Greene, 1934, A. aczeli Blanchard, 1961 and A. bistrigata Bezzi, 1919 (Table 1).

The species A. similis and A. aczeli have not been catalogued in the state of Minas Gerais under the acquis "Dynamic catalogue of Anastrepha species in Brazil of the Department of Entomology at ESALQ/USP", making this study the first record of these species in Minas Gerais, Brazil (DUARTE et al., 2015). These species occur in the states of Rio Grande do Sul (GARCIA; CORSEUIL, 2004) and Santa Catarina (GARCIA et al., 2002), southern Brazil, but their hosts are still unknown (ZUCCHI, 2008), since they were not found inside the fruit. According to Zucchi (2000b), in Brazil the seven most economically important species of Anastrepha are: A. fraterculus, A. grandis, A. obliqua, A. pseudoparallela, A. sororcula, A. striata Schiner, 1868 and A. zenildae. In this research six of the seven species mentioned were found, in addition to the species $C$. capitata which also has great economic importance.

The species A. fraterculus was obtained in traps laid in every fruit present in the orchard (Table 1), which corroborates the statement by Malavasi et al. (2000), reporting that this species is a primary pest of great importance in Argentina, Uruguay, and the Southern and Southeastern states of Brazil. These regions face the highest expenditure on control measures and also the biggest losses due to the occurrence of the pest. In addition, this species has a wide variety of hosts; Zucchi (2015) reports 110 host species, mainly in the family Myrtaceae (38 species), followed by Rosaceae and Rutaceae (13 species and 10 species, respectively). Ceratitis capitata was also found in traps arranged in all fruit trees, being considered as presenting high faunal indices (Table 1); according to Zucchi (2001), this species attacks 58 host species, of which 20 are native, showing its great adaptability to the invaded niche. The fruit fly species found in the area were collected in the traps, and this means they were attracted to them; however, it can be considered that the attraction of the fruit flies to the orchard is due to the host plant, with development of larvae occurring in the fruit, since adults were found over the 10 months of collection.

The largest number of individuals of fruit flies was captured in the citrus orchard, 3,012, while for acerola 219 individuals were found; thus, the citrus proved more attractive to fruit fly species in general. Regarding the species richness, the highest rate was found in citrus and acerola, both with 9 species; the same was observed in relation to the diversity index, and the areas with the largest index had 3,641 (Table 1).

In areas containing fig, cherry and citrus, C. capitata was seen to be more frequent and dominant, with the respective values of occurrence, $81.1 \% ; 68.9 \%$ and $97.1 \%$ (Table 1). These data corroborate those of Uchôa-Fernandes et al. (2003) in studies conducted with McPhail traps in citrus orchards (Citrus sinensis L. and Citrus reticulata L.), where the authors found that $C$. capitata was the most frequent tephritid, being dominant in the citrus area.

It was only in the guava area that the species A. pseudoparallela (55.6\%) had a higher frequency value than the others, and $A$. pseudoparallela and A. fraterculus were also dominant for the fig and acerola crops, along with C. capitata. Regarding the constancy index of the individuals listed for the fig tree crop, only $A$. obliqua was accidental, while the others were classified as incidental. Considering the guava orchard, all species were considered incidental; and for the acerola orchard $C$. capitata was constant, $A$. obliqua and A. zenildae were deemed accidental and the others were incidental (Table 1).

For citrus crop, A. zenildae, A. sororcula, A. similis, A. aczeli, A. bistrigata and A. dissimilis were constant throughout the collection period. Anastrepha fraterculus was incidental, A. grandis and $C$. capitata accidental, although the latter submitted a large number of individuals: however, these were not well distributed over the period, atching the high occurrence in the period with higher availability of fruits (Table 1). 
Table 1. Faunistic analysis of fruit fly species collected in the fig, guava, acerola and citrus orchards at IFMG - Campus Bambuí from November 2011 to August 2012.

\begin{tabular}{|c|c|c|c|c|c|c|c|c|c|c|c|c|c|c|c|c|c|c|c|c|}
\hline \multirow{3}{*}{ SPECIES } & \multicolumn{20}{|c|}{ CROP } \\
\hline & \multicolumn{5}{|c|}{ FIG } & \multicolumn{5}{|c|}{ GUAVA } & \multicolumn{5}{|c|}{ ACEROLA } & \multicolumn{5}{|c|}{ CITRUS } \\
\hline & $\mathrm{N}$ & $\mathrm{F}(\%)$ & $\mathrm{C}($ & & D & $\mathrm{N}$ & $\mathrm{F}(\%)$ & $\mathrm{C}$ & & D & $\mathrm{N}$ & $\mathrm{F}(\%)$ & $\mathrm{C}$ & & D & $\mathrm{N}$ & $\mathrm{F}(\%)$ & $\mathrm{C}$ & & D \\
\hline A. grandis & 7 & 4.27 & 40 & $\mathrm{Y}$ & $\mathrm{N}$ & 1 & 11.1 & 10 & $\mathrm{Z}$ & $\mathrm{N}$ & 7 & 3.2 & 30 & $Y$ & $\mathrm{~N}$ & 32 & 1.06 & 60 & $Y$ & $\mathrm{~N}$ \\
\hline A. fraterculus & 14 & 8.54 & 40 & Y & $\mathrm{N}$ & 1 & 11.1 & 10 & $\mathrm{Z}$ & $\mathrm{N}$ & 45 & 20.5 & 40 & Y & $\mathrm{D}$ & 45 & 1.49 & 50 & $\mathrm{Z}$ & $\mathrm{N}$ \\
\hline A. pseudoparallela & 9 & 5.49 & 30 & $\mathrm{Y}$ & $\mathrm{N}$ & 5 & 55.6 & 20 & $\mathrm{Z}$ & $\mathrm{D}$ & 3 & 1.37 & 30 & $\mathrm{Y}$ & $\mathrm{N}$ & - & - & - & - & - \\
\hline A.obliqua & 1 & 0.61 & 10 & $\mathrm{Z}$ & $\mathrm{N}$ & - & - & - & - & - & 2 & 0.91 & 10 & $\mathrm{Z}$ & $\mathrm{N}$ & - & - & - & - & - \\
\hline A. dissimilis & - & - & - & - & - & - & - & - & - & - & 4 & 1.83 & 30 & $\mathrm{Y}$ & $\mathrm{N}$ & 3 & 0.1 & 20 & $\mathrm{~W}$ & $\mathrm{~N}$ \\
\hline A. zenildae & - & - & - & - & - & - & - & - & - & - & 1 & 0.46 & 10 & $\mathrm{Z}$ & $\mathrm{N}$ & 1 & 0.03 & 10 & W & $\mathrm{N}$ \\
\hline A. sororcula & - & - & - & - & - & - & - & - & - & - & 5 & 2.28 & 10 & $\mathrm{Z}$ & $\mathrm{N}$ & 3 & 0.1 & 10 & W & $\mathrm{N}$ \\
\hline A. similis & - & - & - & - & - & - & - & - & - & - & 1 & 0.46 & 10 & $\mathrm{Z}$ & $\mathrm{N}$ & 1 & 0.03 & 10 & $\mathrm{~W}$ & $\mathrm{~N}$ \\
\hline A.aczeli & - & - & - & - & - & - & - & - & - & - & - & - & - & - & - & 2 & 0.07 & 10 & W & $\mathrm{N}$ \\
\hline A.bistrigata & - & - & - & - & - & - & - & - & - & - & - & - & - & - & - & 1 & 0.03 & 10 & W & $\mathrm{N}$ \\
\hline C. capitata & 133 & 81.1 & 50 & $\mathrm{Y}$ & D & 2 & 22.2 & 10 & $\mathrm{Z}$ & D & 151 & 68.9 & 60 & $\mathrm{~W}$ & $\mathrm{D}$ & 2,924 & 97.1 & 40 & Z & $\mathrm{D}$ \\
\hline TOTAL & 164 & 100 & - & - & - & 9 & 100 & & & & 219 & 100 & & & & 3,012 & 100 & & & \\
\hline $\mathrm{S}$ & 5 & & & & & 4 & & & & & 9 & & & & & 9 & & & & \\
\hline ID & 2,485 & & & & & 2,164 & & & & & 3,641 & & & & & 3,641 & & & & \\
\hline $1 / \mathrm{S}$ & 20 & & & & & 25 & & & & & 11.11 & & & & & 11.11 & & & & \\
\hline
\end{tabular}

N: Number of captured females flies; F: Frequency (\%); S: Richness; ID: Diversity index; C: Constancy (W: Constant, Y: Incidental, Z: Accidental); 
The species richness of fruit flies found in fig, guava, acerola and citrus orchards, respectively 5, 4, 9 and 9 (Table 1), was considered low compared to studies performed in other states, considering that the collection periods and the plants species differ from the other studies. Ferrara et al. (2005) conducted collections with McPhail traps in guava and citrus orchards for 24 months in four different municipalities of northwestern Rio de Janeiro state (Bom Jesus do Itapaboana, Italva, Itaperuna and Natividade) and obtained 16 Anastrepha species and C. capitata. Also in Brazil, Uramoto et al. (2004) recorded a richness of 18 species of Anastrepha in Campus Luiz de Queiroz/USP, Piracicaba, São Paulo state, and attributed this result to the diversity of plant species grown in the area, five species of fruits. However, Aguiar-Menezes et al. (2008) in a study conducted during 26 months and 4 species of fruit in the municipalities of São João da Barra and Cambuci, northern and northwestern state of Rio de Janeiro, obtained what was considered low richness $(S=6)$.

The diversity indices for the orchards were considered low, since for fig, guava, acerola and citrus orchards these were 2,$485 ; 2,164 ; 3,641$; 3,641 , respectively (Table 2). This index rarely exceeds the value 4.5 , typically ranging from 1.5 to 3.5 (MARGALEF, 1972); low values are due to the predominance of some taxonomic groups at the expense of the majority and values above 5.0 denote great biological richness (BEGON et al., 1996). However, according to Silveira Neto et al. (1976), where the limiting factors, such as climatic conditions, interspecific competition, availability of hosts and food, work intensely, the diversity index tends to be lower. Therefore, in agroecosystems it is justifiable to find low levels of diversity, as noted in this study.

\section{Infestation rates}

Infestation rates of fruit flies are demonstrated in Table 2. Critical values of occurrence were achieved by the species $C$. capitata for fig, acerola and citrus crops. Anastrepha spp. (10 species) reached minimum values, and therefore it would not be necessary to perform insect control at this time (Table 2).

Ceratitis capitata in fig crop in July obtained a MAD value of 0.79 ; for acerola in August the value was 0.77; and for citrus in June it was 0.60 (Table 2); these values demonstrated the need to perform pest control. In November 2011, July and August 2012 for citrus, C. capitata reached critical MAD levels, 1.26, 10.20 and 1.69 respectively; and this same species in July 2012 for acerola achieved 1.12 MAD value (Table 2). The MAD index in this period exceeds the value 1, which for some countries could even cause the penalty of suspending exports, requiring immediate control of insect pests (CARVALHO, 2005).

All MAD values found that were considered high are related to the month of greatest availability of fruit; thus, the fruit flies can remain in the environment because of the different fruit species serving as hosts at different times. For guava orchards, rates of fruit-fly occurrence were low, which may have been a result of spraying the insecticide Danimen ${ }^{\circledR}$ (active ingredient fenpropathrin) in the months of December 2011, January and March 2012, corresponding to the period with highest fruit production. The insecticide was applied on the basis of cultural practices routinely carried out in the orchard, without considering the indexes obtained in the collection of fruit flies.

Alberti et al. (2012) conducted a survey of fruit flies in Santa Catarina state, Brazil, in peach and passion fruit orchards, and observed that there was a low infestation of Ceratitis when compared to the occurrence of Anastrepha. Garcia et al. (2003a) in orchards in the West of Santa Catarina found that C. capitata was accidental in almost all orchards where it occurred, except in a citrus orchard, which was incidental, and A. fraterculus was predominant in the four municipalities studied.

Garcia and Corseuil (1998) also stated that A. fraterculus was abundant, constant and frequent, C. capitata was incidental and A. grandis accidental when they evaluated peach orchards in Rio Grande do Sul state, Brazil. Alberti et al. (2009) observed that $A$. grandis and $A$. fraterculus were the most abundant, frequent, constant and dominant species in the studied orchards, predominating over other species of fruit flies, and C. capitata was considered dispersed and accidental. These results differ from thedata obtained in the present work in relation to $C$. capitata, since although different Anastrepha species were found, including some that were considered dominant in some areas, $C$. capitata was the species obtained in the greatest number and most frequently in most areas studied, except for $A$. pseudoparallela in the guava area. Ceratitis capitata was also the species with greatest constancy compared to the others, except for A. fraterculus and A. grandis in the citrus area; then, $C$. capitata may have occurred in the greatest numbers by developing in a wider range of fruit. 
Table 2. Infestation rate (MAD) of fruit fly in fig, guava, acerola and citrus orchards at IFMG - Campus Bambuí from November 2011 to August 2012.

\begin{tabular}{|c|c|c|c|c|c|c|c|c|c|}
\hline \multirow{2}{*}{ Month } & \multirow{2}{*}{ Genus/Species } & \multicolumn{8}{|c|}{ CROP } \\
\hline & & Fig & MAD (1) & Guava & MAD (2) & Acerola & MAD (3) & Citrus & MAD (4) \\
\hline \multirow{2}{*}{ November } & Anastrepha sp. & 0 & 0 & 0 & 0 & 0 & 0 & 0 & 0 \\
\hline & C. capitata & 2 & 0.013 & 3 & 0.02 & 11 & 0.07 & 377 & 1.26 \\
\hline \multirow{2}{*}{ December } & Anastrepha sp. & 0 & 0 & 0 & 0 & 0 & 0 & 0 & 0 \\
\hline & C. capitata & 0 & 0 & 0 & 0 & 0 & 0 & 0 & 0 \\
\hline \multirow{2}{*}{ January } & Anastrepha sp. & 3 & 0.02 & 6 & 0.04 & 5 & 0.03 & 7 & 0.02 \\
\hline & C. capitata & 0 & 0 & 0 & 0 & 8 & 0.053 & 0 & 0 \\
\hline \multirow{2}{*}{ February } & Anastrepha sp. & 1 & 0.01 & 4 & 0.03 & 6 & 0.04 & 1 & 0.01 \\
\hline & C. capitata & 1 & 0.01 & 0 & 0 & 0 & 0 & 0 & 0 \\
\hline \multirow{2}{*}{ March } & Anastrepha sp. & 2 & 0.01 & 0 & 0 & 0 & 0 & 0 & 0 \\
\hline & C. capitata & 0 & 0 & 0 & 0 & 0 & 0 & 0 & 0 \\
\hline \multirow{2}{*}{ April } & Anastrepha sp. & 20 & 0.13 & 0 & 0 & 36 & 0.24 & 27 & 0.09 \\
\hline & C. capitata & 0 & 0 & 0 & 0 & 0 & 0 & 0 & 0 \\
\hline \multirow{2}{*}{ May } & Anastrepha sp. & 10 & 0.07 & 0 & 0 & 26 & 0.17 & 7 & 0.02 \\
\hline & C. capitata & 0 & 0 & 0 & 0 & 6 & 0.04 & 0 & 0 \\
\hline \multirow{2}{*}{ June } & Anastrepha sp. & 3 & 0.02 & 0 & 0 & 6 & 0.04 & 22 & 0.07 \\
\hline & C. capitata & 118 & 0.79 & 0 & 0 & 14 & 0.09 & 179 & 0.60 \\
\hline \multirow{2}{*}{ July } & Anastrepha sp. & 5 & 0.03 & 0 & 0 & 0 & 0 & 54 & 0.18 \\
\hline & C. capitata & 46 & 0.31 & 0 & 0 & 168 & 1.12 & 3059 & 10.20 \\
\hline \multirow{2}{*}{ August } & Anastrepha sp. & 1 & 0.01 & 0 & 0 & 2 & 0.01 & 24 & 0.08 \\
\hline & C. capitata & 21 & 0.14 & 0 & 0 & 115 & 0.77 & 506 & 1.69 \\
\hline \multirow{2}{*}{ TOTAL } & Anastrepha sp. & 45 & 0.30 & 10 & 0.07 & 81 & 0.54 & 142 & 0.47 \\
\hline & C. capitata & 188 & 1.25 & 3 & 0.02 & 322 & 2.14 & 4,121 & 13.74 \\
\hline
\end{tabular}


Garcia et al. (2003b) performed surveys of fruit flies in the western region of Santa Catarina, and found that the population peak of $A$. fraterculus varies according to the year, crops and locations, and that this species occurs in all seasons. In the present work it was verified that $A$. fraterculus and A. grandis were found in all studied orchards, with A. fraterculus found more frequently than $A$. grandis.

According to Zilli and Garcia (2010), A. fraterculus was the only species considered very abundant, very frequent, constant and dominant in a survey conducted in Santa Catarina in a C. sinensis orchard, being considered as predominant. The authors relate this result to the habit of polyphagia found inthis species, which may occur in 67 hosts, belonging to 18 families of plants.

Garcia and Lara (2006) conducted a survey in Santa Catarina in a citrus orchard and reported that $A$. fraterculus was the most abundant, constant, frequent and dominant species, and that it could be regarded as predominant; furthermore, the diversity index obtained by the authors was 1.09 , while in this study this was 3.64. This difference may be due to the diversity of fruit plants located near to the citrus orchard, as acerola, guava and fig, which could be used as hosts for different species. According to Nora (2001) the great diversity of native and cultivated plants facilitates the reproduction of $A$. fraterculus throughout the year; besides that, the population peaks of the fruit flies in citrus orchards varied from year to year and between orchards in the same year, which was also confirmed by Raga et al. (1996) in surveys conducted in citrus orchards in São Paulo state, Brazil.

In this way, it was possible to observe the occurrence of different species of fruit flies in the studied orchard area, and in addition, A. similis and A. aczeli had not been catalogued previously in the state of Minas Gerais.

Periods of higher occurrence of fruit flies were observed when there was greater availability of fruit according to the seasonality of each crop, but the presence of fruit flies was also found outside the production period, showing that alternative hosts can influence the continuing presence of fruit flies in the area. The species constancy can also be influenced by the availability of fruits in the area, and some species of fruit flies could be more specific to a host.

The faunal indices were low in relation to the richness and diversity of species, when compared to other important states in Brazil that produce fruit; $C$. capitata was proved to be the dominant species in all studied fruit.

\section{ACKNOWLEDGMENTS}

The authors thank the Conselho Nacional de Desenvolvimento Científico e Tecnológico $(\mathrm{CNPq})$ and the Fundação de Amparo à Pesquisa do Estado de Minas Gerais (FAPEMIG) for financial support.

RESUMO: As moscas-das-frutas são consideradas importantes pragas da fruticultura mundial, causando perdas significativas à produção e limitando o livre trânsito de frutas devido às restrições impostas pelos países importadores. Dessa forma, teve-se por objetivo estudar os índices de infestação e faunísticos para caracterização da assembleia de moscas-das-frutas em pomar localizado na região de Bambuí, MG, Brasil. Para tanto, foram realizadas coletas semanais com armadilhas caça-moscas penduradas nas copas das árvores, a uma altura de aproximadamente 1,60 m de altura. Foi realizada análise faunística e índices de infestação. As espécies capturadas foram Ceratitis capitata, Anastrepha grandis, A. fraterculus, A. pseudoparallela, A. obliqua, A. dissimilis, A. zenildae, A. sororcula, A. similis, A. aczeli e A. bistrigata. As espécies encontradas variaram durante todo o período estudado, porém apenas $C$. capitata atingiu nível de dano econômico necessitando de um melhor manejo desses insetos nas áreas com citros, acerola e figo. A espécie predominante foi C. capitata.

PALAVRAS-CHAVE: Anastrepha. Ceratitis. Fruticultura. Levantamento. Tefritídeo.

\section{REFERENCES}

AGUIAR-MENEZES, E. L.; SOUZA, S. A. S.; LIMA-FILHO, M.; BARROS, H. C.; FERRARA, F. A. A.; MENEZES, E. B. Faunistic analysis of fruit flies (Diptera: Tephritidae) in the northern and northwestern regions of Rio de Janeiro State, Brazil. Neotropical Entomology, Londrina, v. 37, p. 8-14. 2008. http://dx.doi.org/10.1590/S1519-566X2008000100002 
ALBERTI, S.; BOGUS, G. M.; GARCIA, F. R. M. Flutuação populacional de moscas-das-frutas (Diptera, Tephritidae) em pomares de pessegueiro e maracujazeiro em Iraceminha, Santa Catarina. Biotemas, Florianópolis, v. 25, p. 53-58, 2012. http://dx.doi.org/10.5007/2175-7925.2012v25n2p53

ALBERTI, S.; GARCIA, F. R. M.; BOGUS, G. M. Moscas-das-frutas em pomares de pessegueiro e maracujazeiro, no Município de Iraceminha, Santa Catarina, Brasil. Ciência Rural, Santa Maria, v. 39, p. 1565-1568, 2009. http://dx.doi.org/10.1590/S0103-84782009005000077

ANUÁRIO BRASILEIRO DE FRUTICULTURA 2013. Santa Cruz do Sul: Editora Gazeta, 2013, 136 p. Available at: http://www.grupogaz.com.br/editora/anuarios/show/3853.html. Accessed on: 01 Oct. 2015.

ANUÁRIO BRASILEIRO DE FRUTICULTURA 2014. Santa Cruz do Sul: Editora Gazeta, 2014. 136 p. Available at: http://www.grupogaz.com.br/editora/anuarios/show/4333.html. Accessed on: 01 Oct. 2015.

ARAÚJO, E. L.; MEDEIROS, M. K. M.; SILVA, V. E.; ZUCCHI, R. A. Fruit flies (Diptera: Tephritidae) in the semi-arid region of the State of Rio Grande do Norte, Brazil: host plants and infestation indices.

Neotropical Entomology, Londrina, v. 34, p. 889-894, 2005. http://dx.doi.org/10.1590/S1519566X2005000600003

BEGON, M.; HAPER, J. L.; TOWNSEND, C. R. Ecology: individuals, populations and communities. 3. ed. Oxford: Blackwell Science, 1996. 1068p.

BODENHEIMER, F. S. Precisd'écologie animal. Paris: Payot, 1955. 315p.

CARVALHO, R. S. Metodologia para monitoramento populacional de moscas-das-frutas em pomares comerciais. Cruz das Almas: Embrapa Mandioca e Fruticultura Tropical (Circular Técnica 75), 2005. 17p.

DUARTE, P. A. S.; GARCIA, F. R. M.; ANDALÓ, V. Anastrepha aczeli Blanchard and Anastrepha similis Greene (Diptera: Tephritidae) in Minas Gerais, Brazil. Ciência Rural, Santa Maria, v. 45, p. 1727-1728, 2015. http://dx.doi.org/10.1590/0103-8478cr20140998

FERRARA, F. A. A.; AGUIAR-MENEZES, E. L.; URAMOTO, K.; DE MARCO JR., P.; SOUZA, S. A.; CASSINO, P. C. R. Faunistic analysis of fruit fly (Diptera: Tephritidae) in the northwest region of Rio de Janeiro State, Brazil. Neotropical Entomology, Londrina,v. 34, p. 183-190. 2005.

http://dx.doi.org/10.1590/S1519-566X2005000200006

GARCIA, F. R. M. Fruit fly: biological and ecological aspects. In: BANDEIRA, R. R. (Ed.) Current trends in fruit flies control on perennial crops and research prospects. Kerala: Transworld Research Network, 2009. p. $1-35$.

GARCIA, F. R. M.; CAMPOS, J. V.; CORSEUIL, E. Análise faunística de espécies de moscas-das-frutas (Diptera: Tephritidae) na região Oeste de Santa Catarina. Neotropical Entomology, Londrina, v. 32, p. 421426, 2003a. http://dx.doi.org/10.1590/S1519-566X2003000300006

GARCIA, F. R. M.; CAMPOS, J. V.; CORSEUIL, E. Flutuação populacional de Anastrepha fraterculus (Wiedemann, 1830) (Diptera, Tephritidae) na Região Oeste de Santa Catarina, Brasil. Revista Brasileira de Entomologia, Curitiba, v. 47, p. 415-420, 2003b. http://dx.doi.org/10.1590/s0085-56262003000300009

GARCIA, F. R. M.; CAMPOS, J. V.; CORSEUIL, E. Lista documentada das moscas-das-frutas (Diptera: Tephritidae) de Santa Catarina, Brasil. Biociências, Porto Alegre, v. 10, p. 139-148, 2002.

GARCIA, F. R. M.; CORSEUIL, E. Análise faunística de moscas-das-frutas (Diptera, Tephritidae) em pomares de pessegueiro em Porto Alegre, Rio Grande do Sul. Revista Brasileira de Zoologia, v. 15, p. 1111-1117, 1998. http://dx.doi.org/10.1590/S0101-81751998000100013 http://dx.doi.org/10.1590/S010181751998000400028

GARCIA, F. R. M.; CAMPOS, J. V.; CORSEUIL, E. Lista documentada das moscas-das-frutas (Diptera: Tephritidae) de Santa Catarina, Brasil. Biociências, Porto Alegre, v. 10, p. 139-148, 2002. 
GARCIA, F. R. M.; LARA, D. B. de. Análise faunística e flutuação populacional de moscas-das-frutas (Diptera, Tephritidae) em pomar cítrico no município de Dionísio Cerqueira, Santa Catarina. Biotemas, Florianópolis, v. 19, p. 65-70, 2006.

IBRAF - Instituto Brasileiro de Frutas. 2015. Available at: http://www.ibraf.org.br/estatisticas/est_frutas.asp. Accessed on: 01 Oct. 2015.

MALAVASI, A.; ZUCCHI, R. A.; SUGAYAMA, R. L. Biogeografia. In:MALAVASI, A.; ZUCCHI, R. A. (Ed). Moscas-das-frutas de importância econômica no Brasil: conhecimento básico e aplicado. Ribeirão Preto: Holos, 2000. p. 93-98.

MARGALEF, R. Homage to Evelyn Hutchinson, or why is there an upper limit to diversity. Transactions of the Connecticut Academy of Arts and Sciences, New Haven, v. 14, p. 211-235, 1972.

NORA, I. Mosca-das-frutas (Anastrepha fraterculus) (Wiedemann, 1830) (Diptera: Tephritidae). In: EPAGRI (Ed.) Nashi, a pêra japonesa. Florianópolis: EPAGRI, 2001. p. 284-298.

RAGA, A.; SOUZA FILHO, M. F. DE; SATO, M. E.; CERÁVOLO, L. C. Dinâmica populacional de moscasdas-frutas em pomares de citros de Presidente Prudente, SP. Arquivos do Instituto Biológico, São Paulo, v. 63, p. 23-38, 1996.

SANTOS, O. O.; ANDRADE, L. L.; BITTENCOURT, M. A. L. Moscas-das-frutas (Diptera: Tephritidae) em armadilhas tipo McPhail e frutos hospedeiros no município de Ilhéus, Bahia. Magistra, Cruz das Almas, v. 20 p. 398-402, 2008.

SILVEIRA-NETO, S.; NAKANO, O.; BARBIN, D.; VILLA NOVA, N. A. Manual de ecologia de insetos. São Paulo: Agronômica Ceres, Brazil, 1976. 420 p.

UCHÔA-FERNANDES, M. A.; OLIVEIRA, I. DE; MOLINA, R. M. S.; ZUCCHI, R. A. Biodiversity of frugivorous flies (Diptera:Tephritoidea) captured in citrus grove, Mato Grosso do Sul, Brasil. Neotropical Entomology, Londrina, v. 32, p. 239-246, 2003. http://dx.doi.org/10.1590/S1519-566X2003000200008

URAMOTO, K.; WALDER, J. M. M.; ZUCCHI, R. Biodiversidade de moscas-das-frutas do gênero Anastrepha (Diptera, Tephritidae) no campus da ESALQ-USP, Piracicaba, São Paulo. Revista Brasileira de Entomologia, Curitiba, v. 48, p. 409-414, 2004. http://dx.doi.org/10.1590/s0085-56262004000300018

ZILLI, G.; GARCIA, F. R. M. Análise faunística e flutuação populacional de moscas-das-frutas (Diptera, Tephritidae) em pomar de Citrus sinensis no município de Chapecó, Santa Catarina. Biodiversidade Pampeana, Uruguaiana, v. 8, p. 39-45, 2010.

ZUCCHI, R. A. Espécies de Anastrepha, sinonímias, plantas hospedeiras e parasitoides. In:MALAVASI, A.; ZUCCHI, R. A.(Ed). Moscas-das-frutas de importância econômica no Brasil: conhecimento básico e aplicado. Ribeirão Preto: Holos, 2000a. p. 41-48.

ZUCCHI, R. A. Fruit flies in Brazil - Anastrepha species their host plants and parasitoids. 2008. Available at: www.lea.esalq.usp.br/anastrepha. Accessed on 09 Sept. 2015.

ZUCCHI, R. A. Mosca-do-mediterrâneo, Ceratitis capitata (Diptera: Tephritidae). In: VILELA, E. F.; ZUCCHI, R. A.; CANTOR, F. (Ed). Histórico e impacto das pragas introduzidas no Brasil. Ribeirão Preto: Holos, 2001. p. 15-22.

ZUCCHI, R. A. Taxonomia. In: MALAVASI, A.; ZUCCHI, R. A.(Ed). Moscas-das-frutas de importância econômica no Brasil: conhecimento básico e aplicado. Ribeirão Preto: Holos, 2000b. p. 13-24. 